\title{
Strength Analysis of a Structure for Attachment of a Winch on SUV
}

\author{
Miroslav Blatnický1, Ján Dižo ${ }^{1}$, Mária Štauderová ${ }^{2}$ \\ ${ }^{1}$ Department of Transport and Handling Machines, Faculty of Mechanical Engineering, University of Žilina, 01026 \\ Žilina. Slovak Republic. E-mail: miroslav.blatnicky@fstroj.uniza.sk, jan.dizo@fstroj.uniza.sk \\ ${ }^{2}$ Department of Applied mechanics, Faculty of Mechanical Engineering, University of Žilina, 01026 Žilina. Slovak Re- \\ public. E-mail: maria.stauderova@fstroj.uniza.sk
}

The paper deals with design proposal of a cover part of a strength bumper, which is tasked with creating the outer design lines of an automobile without sharp edges according to legislation in force and also with protecting a vehicle against damage. The cover part serves for covering the strength part of a back strength bumper, which will be equipped with a winch and used in off-road vehicle Nissan Patrol Y61. Another aim is to perform a FEM analysis of the strength part of the bumper loaded by towing force of the winch and thus to verify a safety of the structure. The next solution of the issue will be an approach to real testing, which will verify a correctness of a numerical computations and also fulfilment of the purpose of creating the structure. Bases of FEM analysis and practical experimental verifications of the structure will be also used as a background for granting approvals, certifications and type approval by superior authorities.

Keywords: Numerical analysis, Winch, SUV, Bumper

\section{Acknowledgement}

This work was created during the project "RAILBCOT-Laboratory test bench for railway wheels tread wear analysis", ITMS code 26220220011 with the support of operational programme Science and Research financed by the European Regional Development Fund. This work was also supported by the project no. APVV-0842-11: "The simulator equivalent operating railway load on a test bench".

\section{References}

[1] BLATNICKÝ, M., DIŽO, J. (2016). Analysis of the hydraulic arm for use on a light goods vehicle. Production management and engineering sciences. pp. 351-354. CRC Press Taylor and Francis Group. ISBN 978-1-13802856-2.

[2] HARUŠINEC, J., GERLICI, J., LACK, T. (2011). Contact stress between railway wheel and rail head analysis with the help of the finite element method. In: Prorail 2011: XX. International Conference „Current problems in Rail Vehicles “, Žilina 2011, November 21st-23rd, Slovak Republic, Proceedings, Scientific and technical Society at the University of Žilina. ISBN 978-80-89276-8, pp. 3-16.

[3] GALliKOVÁ, J., POPROCKÝ, R. (2015). Computer-aided analysis and the consequences of failures of the selected vehicle subsystem. In: TRANSCOM 2015: 11th European conference of young researchers and scientists: Žilina, June 22-24, 2015, Slovak Republic. - Žilina: University of Žilina, 2015. - ISBN 978-80-554-1048-7. - S. 58-63.

[4] GALLIKOVÁ, J., RUMAN, F. (2015). Using of technical diagnostics for an analysis of failure causes and consequences of a selected vehicle. In: Logistyka. - ISSN 1231-5478. - Nr. 4 (2015).

[5] GERLICI, J., LACK, T., HARUŠINEC, J. (2013). The test stand load modulus implementation for the realistic railway operation in the laboratory conditions. In: Manufacturing Technology, Vol. 13, Issue 7, 2013, Pages 444449. ISSN 1213-2489.

[6] KLIMENDA, F., SKOČILASOVÁ, B. (2015). Rollers vibration of pipe conveyor. In: Manufacturing Technology, Vol. 15, Issue 6, 2015, Pages 991-995. ISSN 1213-2489.

[7] LACK, T., GERLICI, J. (2013). Wheel/rail contact stress evaluation by means of the modified strip method. In: Komunikacie, Vol. 15, Issue 3, 2013, Pages 126-132. ISSN 1335-4205.

[8] SMETANKA, L., GERLICI, J., LACK, T., PELAGIC, Z. (2015). Homogenization of fibers reinforced composite materials for simulation analysis. In: Manufacturing Technology, Vol. 15, Issue 5, 2015, Pages 914-920. ISSN 1213-2489.

[9] SVOBODA, M., SOUKUP, J., JELEN, K., KUBOVÝ, P. (2015). Effect of impacts on human head. In: Manufacturing Technology, Vol. 15, Issue 2, 2015, Pages 226-231. ISSN 1213-2489.

[10] www.zbierka.sk, Zbierka zákonov č. 116/1997 Čiastka 54.

[11] www.allmetal.sk 